\title{
Investigating the Ethics of DNA Collection by CODIS
}

\author{
Tanay Subramanian ${ }^{1}$ and Alicia Kerr ${ }^{1}$ \\ ${ }^{1}$ Dougherty Valley High School, San Ramon, CA, USA \\ DOI: https://doi.org/10.47611/jsrhs.v10i2.1439
}

\section{$\underline{\text { ABSTRACT }}$}

America's criminal justice system has experienced controversy for decades and it seems as if the Combined DNA Index System (CODIS), an FBI criminal justice database that stores the DNA profiles of millions of Americans, is a major contributor to it. Due to CODIS, an individual's DNA is collected and permanently stored upon arrest, resulting in major red flags like privacy violations and marginalization. However, there are potential solutions - although each has its drawbacks - to this problem, in order of increasing efficacy: mandating the DNA collection of all Americans to alleviate biases, adopting a solely fingerprint-based system as forensic evidence, and terminating CODIS entirely.

\section{Context: Criminal Justice Today}

Politicians, lawyers, and activists in the United States have debated the flaws in the American criminal justice system for decades. The debate has recently reached a climax, with the advent of the "Black Lives Matter" protests, raising awareness about the racial inequities in American law enforcement. The Combined DNA Index System (CODIS), an FBI criminal justice database that collects and stores the DNA profiles of millions of Americans across the country (Frequently Asked, n.d.), unfortunately, contributes to this. Upon arrest, the individual's DNA is collected and stored by the database indefinitely. DNA or deoxyribonucleic acid is the genetic makeup of an individual, determining physical characteristics, behavioral traits, and family history. While CODIS intends to aid the FBI in investigations, the grim reality is that it has evolved into a biased institution. The FBI is an organization that we look up to for protecting our citizens. However, this is no longer the case as Aziza Ahmed, a professor of law from Harvard Law School, reveals the immoralities of DNA collection by CODIS, like privacy violations, susceptibility to wrongful convictions, and the potential to give the federal government superfluous biometric information, resulting in abuses of power (Ahmed, 2019).

\section{Privacy Infringements by CODIS}

The first perspective questioning CODIS's ethicality is its privacy violations. Peter Chow-White, a Ph.D. in communications from UCLA, and Troy Duster, a sociologist from UC Berkeley, agree that the privacy of those whose DNA is collected is at stake. This is because businesses and hackers can mine this intimate knowledge from databases without user permission, resulting in a significant data breach (Chow-White \& Duster, 2011). David Pozen from The University of Chicago School of Law has reservations about this perspective by elucidating that restricting CODIS's ability to collect DNA upon arrest or suspicion may lead to additional privacy violations elsewhere because as one form of privacy is protected, another form is inevitably jeopardized (Pozen, 2016, pp. 221-247). Thus, the United States government must weigh distributing the DNA samples of many individuals from CODIS - when some of these individuals may be incorrectly suspected - with catching criminals. Chow-White and Duster share a secondary notion: CODIS causes minorities to be overrepresented, leading to future surveillance targeting them (Chow-White \& Duster, 2011). These minorities will be more likely than ethnic majorities - who have less of their DNA collected - to be linked to the crime since law enforcement matches the DNA from the crime scene to its stored samples. Abigail Hauslohner, 
a Columbia University graduate and reporter on immigrants from the Washington Post, sheds further light on this iniquity of ethnicity by explaining that with the modification of the 2005 DNA Fingerprints Act, the DNA of all immigrants will be collected, regardless of a previous history of crime, to match DNA evidence in future crimes (Hauslohner, 2020). Unfortunately, this forms an unethical system whereby the government surveillances minorities and immigrants, violating their privacy, potentially leading to wrongful convictions and stigmatization of these

\section{WRONGFUL CONVICTIONS}

groups.

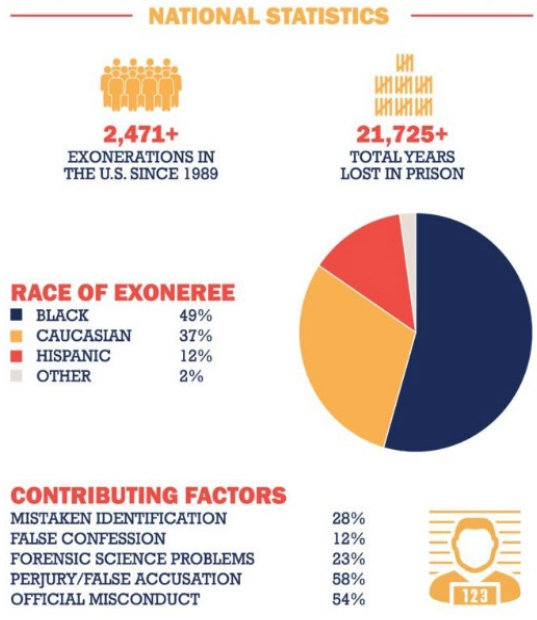

Figure 1. Wrongful convictions disproportionately affecting minorities

\section{Wrongful Convictions from CODIS}

Aside from the unethical clash of privacy and racial bias, CODIS is susceptible to wrongful convictions. Hauslohner also elucidates that after DNA is collected, it can be contaminated during DNA testing, which victimizes immigrants and minorities (Hauslohner, 2020). Here too, certain groups get adversely impacted due to their overwhelming DNA presence in CODIS. It is important to note that these DNA errors also wrongfully convict majority populations to a lesser extent since an individual's DNA can be contaminated to match future DNA investigations, tarnishing the individual's identity. Besides DNA storage errors in the federal database, Brandon Keim, a leading science journalist at WIRED, explicates that the police unfairly collect DNA from people close to the crime scene and through familial connections of suspects, even if their DNA is loosely connected to the forensic DNA on the scene, again over-representing minor ethnic groups, while leaving ethnic majorities with a greater possibility to evade crime (Keim, 2011). Therefore, DNA databases have the potential to be used effectively in law enforcement but currently, their usage targets minorities that cause police to have a bias towards these groups when investigating future cases, leading to wrongful convictions (shown in Figure 1). This viewpoint is supported by Linda Bartusiak, a well-regarded economist from The University of Pennsylvania School of Law. She clarifies that CODIS stores the DNA of arrestees who are later unconvicted and of convicted people after their prison sentence is over, which results in false convictions of these individuals and their families since DNA from the crime scene can be partially matched to these individuals who have no suspicion of wrongdoing, through the database. As a result, investigators can probe the person's relatives, although no individualized suspicion may be present. This comes into direct conflict with the search or seizure requirement of having individualized suspicious activity, violating the person's reasonable expectation of privacy (Bartusiak, 2011, pp. 1115-1139). 


\section{Government's Abuse of Power in CODIS}

The final angle of CODIS's unethicality is the possibility to give excessive power to the federal governments with biometric information about the American population. Bobby Naude, an expert on molecular biology, states that the government can amend existing legislation to expand its applications of the DNA samples in CODIS, as shown in Figure 2. With intel on virtually every aspect of American citizens and their behavior, the government can control our lives, which unethically jeopardizes individual privacy and freedom (Naude, 2010, pp. 213-238). Thus, the government can overstep its powers to become authoritative, threatening democracy. Brooke Auxier and her team from the Pew Research Center, a nonpartisan research organization, maintain Naude's notion by sharing that most Americans don't feel in control of their personal data, with $84 \%$ of Americans agreeing that they have little control over the data that the government collects about them, and $78 \%$ of U.S. adults share that they have little knowledge about what the government actually does with that data (Auxier et al., 2019). Evidently, the government can take advantage of the

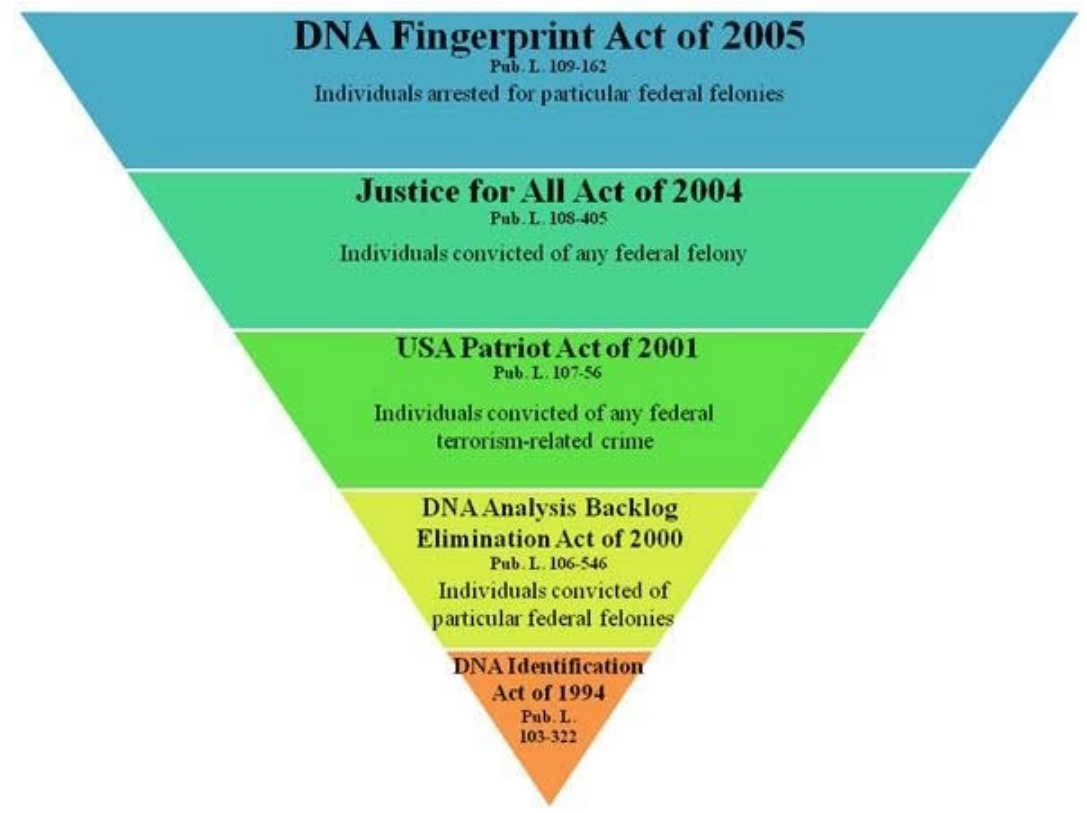

inadequate data and privacy knowledge of most Americans by continuing to harness increasingly personal information without much awareness from citizens.

Figure 2. Expansion of circumstances in which DNA is collected since 1994

\section{Controversy over the Legitimacy of Privacy Violations by CODIS}

Proponents of CODIS argue that individuals' privacy is not infringed upon by CODIS. David Kaye, a graduate of The Yale Law School, cites that supporters of DNA collection by CODIS argue that the stored DNA samples do not reveal information beyond personal identification, so there isn't an invasion of privacy. However, Kaye explicates that this perspective establishes a false, fluid, and arbitrary line of allowed privacy invasion (Kaye, 2014, pp. 535-595). In other words, if government databases can ethically and legally identify people with minor privacy infringement, this limit may gradually increase, threatening public privacy. Amy Jeanguenat, a forensic expert from The Forensic Technology Center of Excellence, shares that CODIS expanded its collection of DNA from the usual 13 loci to 20 loci on January 1 of 2017 (shown in Figure 3), insinuating that future expansion is probable (Jeanguenat, 2017). Therefore, 
current legislation can be amended to expand the applications of DNA, as previously explained by Bobby Naude, which can lead to government abuse by storing more loci from people - aside from loci purely for personal identification - when collecting DNA.

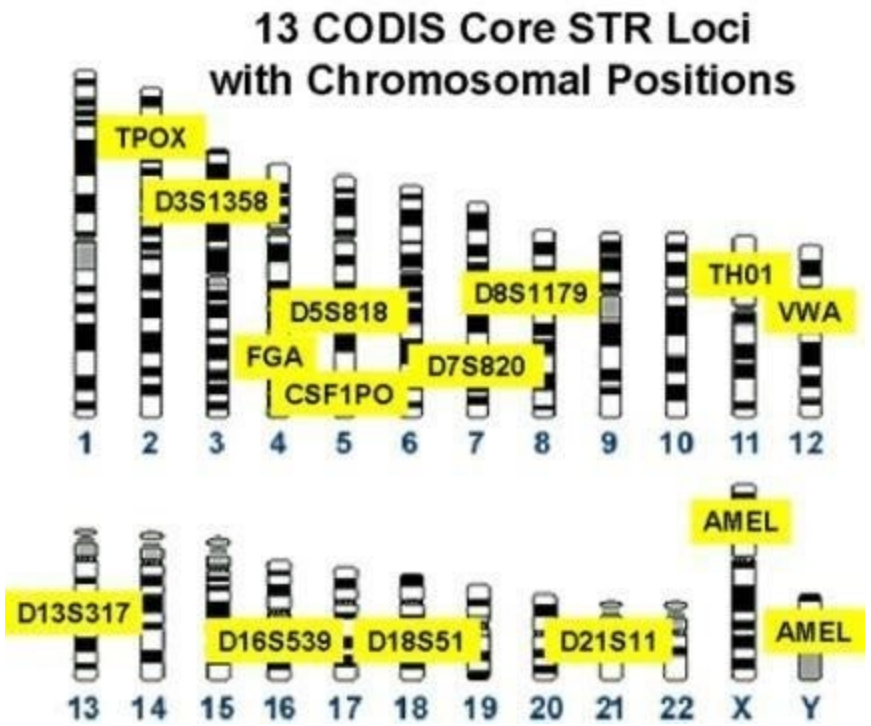

Figure 3. Original 13 locations of chromosomes collected upon conviction

\section{Potential Solutions}

The weakest solution would be to expand the scope of the Combined DNA Index System to include the DNA profiles of all individuals residing in the United States. Some benefits of this include no disproportionate representation of one ethnic group since everyone is included (Hazel, 2018). Furthermore, it would prevent police from unfairly searching or targeting people, protecting the 4th amendment, and eliminating function creep, the use of information outside of its purpose. Lastly, it would continue the economic and social benefits of CODIS by retaining all profiles for greater security. However, the disadvantages of this solution are replete. Collecting DNA from everyone would be a violation of privacy and rights (Lowenberg, 2011). Specifically, it would be a violation of the 4th amendment - protection against unreasonable search and seizure. Moreover, it would increase the risk of false positives due to an influx of profiles and the transfer of additional data (Wessel 2019). Lastly, the practicality of this solution is not evident as it is difficult to obtain consent to collect DNA from everyone

A second, more plausible solution would be to collect fingerprints - instead of DNA - for the purpose of identification upon arrest. Some advantages of this include straying away from DNA, which contains sensitive information that can be used against you in the future in the forms of genetic discrimination (Ford, 2018). More importantly, fingerprints are more accurate than DNA evidence since evidence from the U.S. Department of Commerce shows that fingerprint samples accurately match the individual approximately $99.8 \%$ of the time, resulting in fewer false convictions (U.S. Department of Commerce, National Institute of Standards and Technology, 2012). However, there are some concerns about adopting a fingerprint-based system. Namely, all of the DNA collected at crime scenes so far will become futile. Moreover, those who commit crimes and leave no fingerprint evidence have a lower likelihood of being convicted, so there is a greater chance to evade conviction. Finally, compared to fingerprint evidence, DNA evidence is five times more likely to lead to an arrest and nine times more likely to lead to a conviction (Cronen, 2008).

The final, most effective solution would be to remove all of the millions of DNA forensic profiles and abolish CODIS in its entirety, allowing no further profiles to be inputted. The strengths of this approach include alleviating 
racial biases from CODIS and removing the targeting of immigrants as per the 2005 DNA Fingerprints Act. Furthermore, this protects the privacy of people since the possibility of companies data mining this personal information is stripped, and unfair proximal and familial connections can longer be made (Keim, 2011). Lastly, it significantly reduces the possibility of wrongful convictions due to collection or storage errors. Nevertheless, some drawbacks to eliminating CODIS entirely are that there is currently no alternate system to store identification information for investigating crime, meaning that the government would need to spend valuable time and money searching for another option. In addition, the court has a heavy reliance on DNA today, as shown through $72 \%$ of jurors anticipating to see DNA in a sexual assault trial and juries being 33 times more likely to convict when presented with DNA evidence (Waltke et al., 2017). Hence, eradicating CODIS could mean less reliable and numerable evidence for jurors to depend on when making a ruling.

\section{The Future of Law Enforcement}

Examining the issue of CODIS in law enforcement and the criminal justice system today from an ethical lens reveals that there are diverse perspectives on the topic, including the institution's privacy violations, wrongful convictions, and potential for the United States to be unethically governed by expanding the uses of DNA. Some limitations of this study are that during the creation of this review, DNA evidence has become even more prevalent as the primary source of evidence - George Floyd's DNA from bloodstains in the police car has recently led to charges for Derek Chauvin (Donaghue, 2021) - meaning that as time goes by, it will become increasingly difficult to redress the flaws associated with this method of evidence since the public and courts see many successes with DNA bringing justice, but not the concealed consequences of DNA sampling. Nevertheless, assessing the validity of the different opinions clarifies that disadvantages of CODIS outweigh its benefits, so the United States federal government needs to reevaluate this unjust system with a solution that addresses marginalization while also considering the time and costs.

\section{Acknowledgments}

Thank you to Mrs. Kerr for advising me in this research.

I greatly appreciate her valuable time and knowledge in directing me towards various resources and contacts. These findings wouldn't have been possible without her constructive suggestions, guidance, and thought-provoking questions.

\section{Reference}

Ahmed, A. (2019, January 14). Ethical concerns of DNA databases used for crime control. Harvard Law - Bill of Health. Retrieved January 15, 2021, from https://blog.petrieflom.law.harvard.edu/2019/01/14/ethical-concerns-ofdna-databases-used-for-crime-control/

Auxier, B., Rainie, L., Anderson, M., Perrin, A., Kumar, M., \& Turner, E. (2019, November 15). Americans and privacy: Concerned, confused and feeling lack of control over their personal information. Pew Research Center. Retrieved November 1, 2020, from https://www.pewresearch.org/internet/2019/11/15/americans-and-privacy-concerned-confused-and-feeling-lack-of-control-over-their-personal-information/

Bartusiak, L. (2011). Plea bargaining for DNA: Implications on the right to privacy. The University of Pennsylvania Journal of Constitutional Law, 13(4), 1115-1139. https://scholarship.law.upenn.edu/cgi/viewcontent.cgi?article $=1095 \&$ context $=\mathrm{jcl}$ 
Chow-White, P., \& Duster, T. (2011, October 1). Do health and forensic DNA databases increase racial disparities? National Center for Biotechnology Information. Retrieved October 26, 2020, from https://www.ncbi.nlm.nih.gov/pmc/articles/PMC3186804/

Cronen, E. (2008, June 16). DNA More Effective Than Fingerprints in Solving Property Crimes. Retrieved November 16, 2020, from http://webarchive.urban.org/publications/901179. html\#: :text=Compared \%20to\%20fingerprint $\% 20$ evidence $\% 20$ alone,to $\% 201$ ead $\% 20$ to $\% 20$ an $\% 20$ arrest

Donaghue, E. (2021, April 8). Derek Chauvin trial 4/7/21: Forensic scientist found George Floyd's blood, pills with his DNA in squad car. CBS News. Retrieved April 20, 2021, from https://www.cbsnews.com/live-updates/derechauvin-trial-george-floyd-death-day-8-2021-04-07/

FBI CODIS core STR loci. (2015, August 26). National Institute of Standards and Technology. Retrieved December 24, 2020, from https://strbase.nist.gov/fbicore.htm

Ford, M. (2018, April 30). The New Republic. Retrieved October 19, 2020, from https://newrepublic.com/article/148170/supreme-court-rewrite-rules-dna-searches

Frequently asked questions on CODIS and NDIS [Fact sheet]. (n.d.). Federal Bureau of Investigation (FBI). Retrieved October 26, 2020, from https://www.fbi.gov/services/laboratory/biometric-analysis/codis/codis-and-ndisfact-sheet

Hauslohner, A. (2020, March 6). U.S. immigration authorities will collect DNA from detained migrants. The Washington Post. Retrieved October 26, 2020, from https:/www.washingtonpost.com/immigration/us-immigration-authorities-will-collect-dna-from-detained-migrants/2020/03/06/63376696-5fc7-11ea-9055-5fa12981bbbf_story.html

Hazel, J. (2018). Is it time for a universal genetic forensic database? Retrieved October 27, 2020, from https://scholarship.law.vanderbilt.edu/faculty-publications/1044/

[Infographics]. (n.d.). The National Registry of Exonerations. Retrieved December 24, 2020, from http://www.law.umich.edu/special/exoneration/Pages/about.aspx

Jeanguenat, A. (2017, January). In brief: Applying internal validation guidelines for expanded STR loci kits. Forensic Technology Center of Excellence. Retrieved October 26, 2020, from https://forensiccoe.org/report-validationguidelines-for-expanded-str-loci-kits/

Kaye, D. H. (2014). Why so contrived? Fourth amendment balancing, per se rules, and DNA databases after "Maryland v. King." The Journal of Criminal Law and Criminology (1973-), 104(3), 535-595.

Keim, B. (2011, October 7). Forensic DNA could make criminal justice less fair. WIRED. Retrieved October 26 , 2020, from https://www.wired.com/2011/10/forensic-dna/

Lowenberg, K. (2011, October 17). Applying The Fourth Amendment When DNA Collected for one Purpose is Tested For Another. Retrieved November 16, 2020, from https://law.stanford.edu/wp-content/uploads/2011/11/APPLYING-THE-FOURTH-AMENDMENT-WHEN-DNA-COLLECTED-FOR-ONEPURPOSE.pdf

Naude, B. (2010). The retention of DNA data and the private-life interests of suspects. The Comparative and International Law Journal of Southern Africa, 43(2), 213-238. 
Pozen, D. E. (2016). Privacy-Privacy Tradeoffs. The University of Chicago Law Review, 83(1), 221-247.

U.S. Department of Commerce, National Institute of Standards and Technology. (2012, February). Latent print examination and human factors: Improving the practice through a systems approach. National Institute of Standards and Technology. Retrieved February 18, 2021, from https://tsapps.nist.gov/publication/get_pdf.cfm?pub_id=910745

Wagner, J. (2012, September 21). ENCODE, CODIS, and the urgent need to focus on what is scientifically and legally relevant to the DNA fingerprinting debate. The Privacy Report. Retrieved December 24, 2020, from https://theprivacyreport.com/2012/09/21/encode-codis-and-the-urgent-need-to-focus-on-what-is-scientifically-andlegally-relevant-to-the-dna-fingerprinting-debate/

Waltke, H., LaPorte, G., Weiss, D., Schwarting, D., Nguyen, M., \& Scott, F. (2017, November 9). Sexual assault cases: Exploring the importance of non-DNA forensic evidence. National Institute of Justice. Retrieved November 15, 2020, from https://nij.ojp.gov/topics/articles/sexual-assault-cases-exploring-importance-non-dna-forensic-evidence

Wessel, L. (2019, October 07). Scientists concerned over US plans to collect DNA data from immigrants. Retrieved November 17, 2020, from https://www.nature.com/articles/d41586-019-02998-3 